\title{
Absorption of pollutants from exhaust gases by low- temperature heating surfaces
}

\author{
Victoria Kornienko ${ }^{1 *}$, Mykola Radchenko ${ }^{1}$, Roman Radchenko ${ }^{1}$, Marcin Kruzel $^{2}$, Dmytro Konovalov ${ }^{1}$ and Andrii \\ Andreev $^{1}$ \\ ${ }^{1}$ Admiral Makarov National University of Shipbuilding, 9 Heroes of Ukraine Avenue, Mykolayiv, Ukraine \\ ${ }^{2}$ Koszalin University of Technology, 2 Śniadeckich Street, Koszalin 75-453, Poland
}

\begin{abstract}
One of the most effective methods aimed to improving the environmental safety is fuel oil combustion in the form of specially prepared water-fuel emulsions. The combustion of water-fuel emulsion in internal combustion engines makes it possible to reduce a rate of low-temperature corrosion at wall temperatures below the dew point temperature of sulfuric acid vapor, to install a condensing lowtemperature heating surface in the exhaust gas boiler that leads to increase the efficiency of boiler. Therefore, it is of great importance to assess the effect of the presence of condensate (water, acid) and pollution on these surfaces on the processes of $\mathrm{NO}_{x}, \mathrm{SO}_{2}$ absorption from exhaust gases. Investigations of $\mathrm{SO}_{2}, \mathrm{NO}_{\mathrm{x}}$ and particulate matter emission were carried out on the experimental installation for fuel oil and water-fuel emulsion combustion with different water content. Using condensing heating surface enables to reduce the concentration of $\mathrm{NO}_{\mathrm{x}}$ and $\mathrm{SO}_{2}$ by $65 \%$. Experimental studies have shown that condensing heating surface ensures the capture of up to $30 \%$ of particulate matter from the exhaust gas flow.
\end{abstract}

\section{Introduction}

One of the most perspective methods aimed to enhancing the environmental safety of atmospheric and water basin is fuel oil combustion in the form of specially prepared water-fuel emulsions (WFE) [1]. The use of wastewater as additional water makes it possible to focus the thermal power plants to low-waste technology by utilizing all wastewater contaminated with fuel products. The increased efficiency of the WFE combustion process is provided through the microexplosions of its droplets [2,3], due to which the process of mixing fuel with air is improved, as a result the process of fuel oil combustion is intensified, that leads to decrease in the emission of particulate matter (PM), $\mathrm{NO}_{x}$ and $\mathrm{SO}_{2}$ oxides $[4,5]$.

In addition, the WFE combustion in internal combustion engines makes it possible to reduce the lowtemperature corrosion (LTC) rate at wall temperatures below the dew point temperature of sulfuric acid vapor $[6,7]$, to install a condensing low-temperature heating surface (LTHS) in the exhaust gas boiler (EGB) and thereby increase the EGB efficiency $[8,9]$ and thermal power plant $[10,11]$.

\section{Literature review}

Since the use of condensing heating surfaces determines the possibility of increasing the efficiency of boiler [12, 13], it is of great importance to assess the effect of the presence of condensate (water, acid) and pollution [14-
16] on the LTHS on processes of $\mathrm{NO}_{\mathrm{x}}$ conversion during the movement of gases in the gas duct and in the atmosphere, on the amount of $\mathrm{SO}_{2}$ in exhaust gases

Exhaust gases of power boilers nitrogen oxides $\mathrm{NO}_{\mathrm{x}}$ consist of $97 \%$ of $\mathrm{NO}$ and $5 \%$ of $\mathrm{NO}_{2}$ [17]. For auxiliary boilers and industrial boilers, according to [18] the content of $\mathrm{NO}_{2}$ in NOx significantly increases (the proportion of nitrogen dioxide reaches $12 \%$ ). When water vapor is injected into the combustion chamber of a gas turbine an increase of $\mathrm{NO}_{2}$ content up to $38 \%$ is observed [19].

Conversion and absorption of higher oxides of sulfur and nitrogen by water and solutions of other liquids is used in a number of technologies for cleaning exhaust gases from toxic ingredients $\mathrm{SO}_{x}$ and $\mathrm{NO}_{x}[20,21]$. The introduction of ozone into exhaust gases ensures the oxidation of lower oxides of sulfur and nitrogen $\left(\mathrm{SO}_{2}\right.$ and $\mathrm{NO}$ ) to higher oxides ( $\mathrm{SO}_{3}$ and $\mathrm{N}_{2} \mathrm{O}_{5}$ ), well absorbed by water and aqueous solutions.

The passage of the nitrous mechanism of $\mathrm{H}_{2} \mathrm{SO}_{4}$ formation in the condensate at the LTHS (in the pollution layer) during the WFE combustion should have an impact on the emission of $\mathrm{SO}_{\mathrm{x}}$ and $\mathrm{NO}_{\mathrm{x}}$ into the atmosphere. Therefore, it is necessary to assess the environmental indicators of EGB during the WFE combustion, providing the nitrous mechanism of formation of $\mathrm{H}_{2} \mathrm{SO}_{4}$ passes through the layer of pollutions at wall temperatures below the dew point temperature of sulfuric acid vapor $[6,16]$.

When WFE was burnt with $W^{r}=30 \%$, the $\mathrm{NO}_{2} / \mathrm{NO}$ ratio is closer to the equimolar ratio $(0.5)$ than while

* Corresponding author: kornienkovika1987@gmail.com 
burning fuel oil M40 and diesel fuel. Consequently, during the WFE combustion, a better absorption of $\mathrm{NO}_{\mathrm{x}}$, as well as $\mathrm{SO}_{2}$, should occur. The nature of the change in the $\mathrm{SO}_{2}$ content with increasing $W^{r}$ is practically the same for all types of fuels and is directed towards a decrease in concentration.

It has been experimentally proved [22] that the rate of absorption of nitrogen oxides $\mathrm{NO}_{\mathrm{x}}$ by condensate $\mathrm{H}_{2} \mathrm{SO}_{4}$, consisting of an equimolecular mixture of $\mathrm{NO}$ and $\mathrm{NO}_{2}\left(50 \% \mathrm{NO}\right.$ and $\left.50 \% \mathrm{NO}_{2}\right)$, is almost 2 times higher than from a gas containing only $\mathrm{NO}_{2}$ or $\mathrm{NO}$. The main influence on the rate of $\mathrm{NO}_{x}$ absorption is exerted by chemical processes occurring in the liquid phase [23].

Modern methods, including ANSIS [24-26], can be used for simulation [27, 28] and optimizing [29-31] the processes and regimes of operation as well as statistical treatment of experimental data [32-34]. For estimating the efficiency of such greening and fuel saving technologies during the operation in actual climatic conditions various methods of modelling $[35,36]$ are applied.

The aim of research is to assess the effect of the presence of condensate (water, acid) on condensing LTHS on the processes of $\mathrm{NO}_{x}, \mathrm{SO}_{2}$ and $\mathrm{PM}$ absorption from exhaust gases during WFE combustion.

\section{Research methodology}

\subsection{Experimental research}

Investigations of the $\mathrm{SO}_{\mathrm{x}}$ and $\mathrm{NO}_{\mathrm{x}}$ emission were carried out on an experimental installation (Fig. 1, a) with fuel oil and WFE based on this fuel oil combustion [37, 38] with different water content with an almost constant excess air ratio.

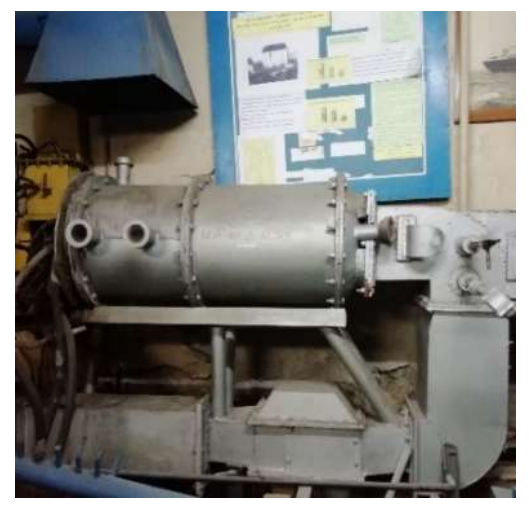

$a$

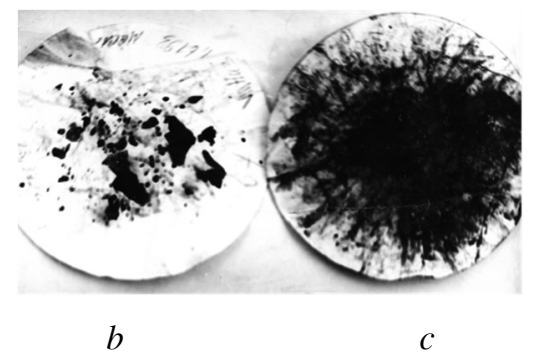

Fig. 1. General view of the experimental setup (a) fabric filter during WFE (b) and fuel oil (c) combustion.
The analysis of the exhaust gases composition was carried out with an OXI-5M gas analyzer behind the furnace and LTHS.

In order to assess the decrease of PM emission, experimental studies of their concentration in exhaust gas flow before and after the LTHS were carried out, depending on the water content of WFE. The values of PM concentration before and after LTHS were determined by filtering the exhaust gas flow using a glass cloth filter and checked by calculation (Fig.1, b, c).

\subsection{Theoretical research}

The mass flow rate of soot particles (SP) in the exhaust gas flow after LTHS has been determined by the formula [39], g/h:

$$
G_{S P \text { in flow }}^{\text {after LTHS }}=\frac{q_{4} \cdot 10^{3} \cdot Q_{p}^{r}}{10^{2} \cdot Q_{i}^{r}},
$$

where $Q_{i}^{r}=32800 \mathrm{~kJ} / \mathrm{kg}, Q_{p}^{r}=39360 \mathrm{~kJ} / \mathrm{kg}$ - the lowest and highest heat of fuel combustion (fuel oil M100).

The mass flow rate of PM in the exhaust gas flow before LTHS has been determined by volume concentration, g/h:

$G_{P M \text { in flow }}^{\text {after LTHS }}=f\left(C_{P M \text { in flow }}^{\text {before LTHS }}\right)=C_{P M}^{\text {before } \text { in flow }} \cdot V_{\text {gas flow }} \cdot 10^{-3}$

where $V_{\text {gas flow }}=15 \mathrm{~m}^{3} / \mathrm{kg}$ - volume flow rate of exhaust gases through the gas duct of experimental setup.

The experimental value of the volume concentration of PM in exhaust gas flow before LTHS $C_{P M}^{\text {before } \text { in flow }}$ at corresponding water contents of WFE, $\mathrm{mg} / \mathrm{m}^{3}$.

The mass flow rate of PM deposited on the LTHS $G P M$ settle has been determined at the number of deposits $\mathbf{D}_{p}, \mathrm{~g} / \mathrm{h}$ :

$$
G_{P M \text { settle }}=K_{p} \cdot S
$$

where $K_{p}$ - the estimated number of deposits on LTHS of experimental setup, $\mathrm{g} /\left(\mathrm{m}^{2} \cdot \mathrm{h}\right)[14]$;

The total area of the outer surface of the experimental samples installed in the gas duct of the experimental setup:

$$
S=\pi d l n
$$

The diameter of the experimental sample is $d=$ $25 \mathrm{~mm}=0.025 \mathrm{~m}$, its length is $l=80 \mathrm{~mm}=0.08 \mathrm{~m}$, the number of installed samples is $n=13$. Thus, $S=0.082 \mathrm{~m}^{2}$.

The volume concentration of PM deposited on LTHS has been determined by mass flow rate, $\mathrm{mg} / \mathrm{m}^{3}$ : 


$$
C_{P M \text { settle }}=\frac{G_{P M \text { settle }} \cdot 10^{3}}{V_{\text {gas flow }}}
$$

The volume concentration of PM after LTHS was determined, $\mathrm{mg} / \mathrm{m}^{3}$ :

$$
C_{P M \text { in flow }}^{\text {after LTHS }}=C_{P M \text { in flow }}^{\text {before LTHS }}-C_{P M \text { settle }}
$$
$\%:$

The "degree of capture" LTHS has been determined,

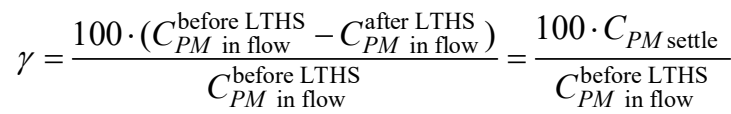

The total toxicity index for the maximum concentrations of ingredients has been determined

$$
\Phi_{\Sigma}=\frac{C_{\mathrm{NOx}}}{\Pi Д \kappa_{\mathrm{NOx}}}+\frac{C_{\mathrm{SO}_{2}}}{\Pi Д \kappa_{\mathrm{SO}_{2}}}
$$

\section{Results}

Experimental studies have shown that a decrease of $\mathrm{NO}_{\mathrm{x}}$ and $\mathrm{SO}_{2}$ concentration with an increase in $W^{r}$ in the WFE is accompanied by an increase of the aerosol $\mathrm{H}_{2} \mathrm{SO}_{4}$ content, which is observed at $W^{r}=10 \%$ and above. The same process takes place in sulfuric acid production by the nitrous mechanism. The results of investigation the content of $\mathrm{NO}_{\mathrm{x}}, \mathrm{SO}_{2}$ in exhaust gas flow with an increase of water content in the emulsion to $30 \%$ are shown in Fig. 2 .

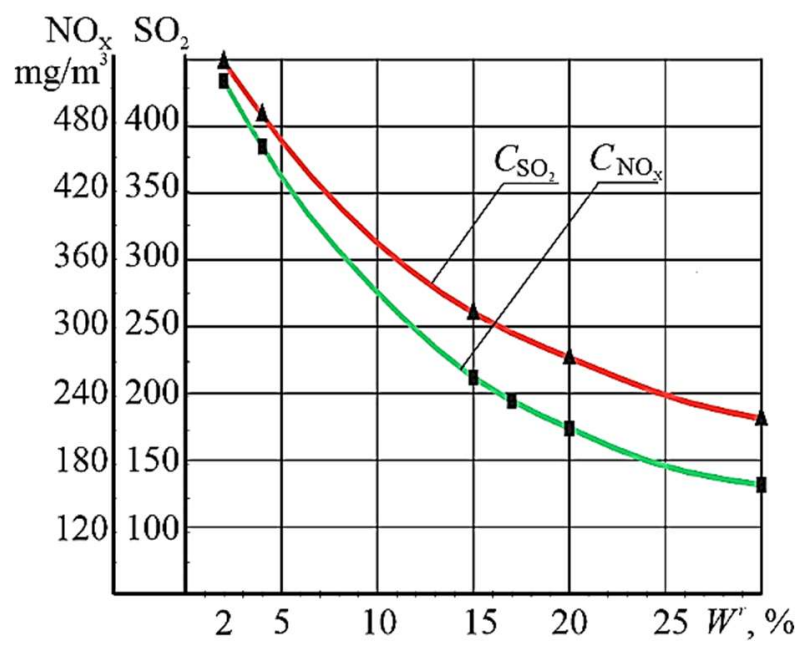

Fig. 2. Influence of water content of WFE on the $\mathrm{NO}_{\mathrm{x}}$ and $\mathrm{SO}_{2}$ emission.

The dependence of the concentration of $C_{P M}$ of solid ash and soot particles (particulate matter) in the exhaust gas flow before and after the LTHS during WFE combustion with different $W^{r}$ in Fig. 3-4 have shown.

It shows a sharp decreasing of $C_{\mathrm{PM}}$ concentration almost 3 times with an increasing of the water content of WFE from 2 to $15 \%$. This is explained by an increasing of the plume turbulence due to the effect of "microexplosion" of WFE droplets, which leads to their additional fragmentation and better burnout PM of smaller size.

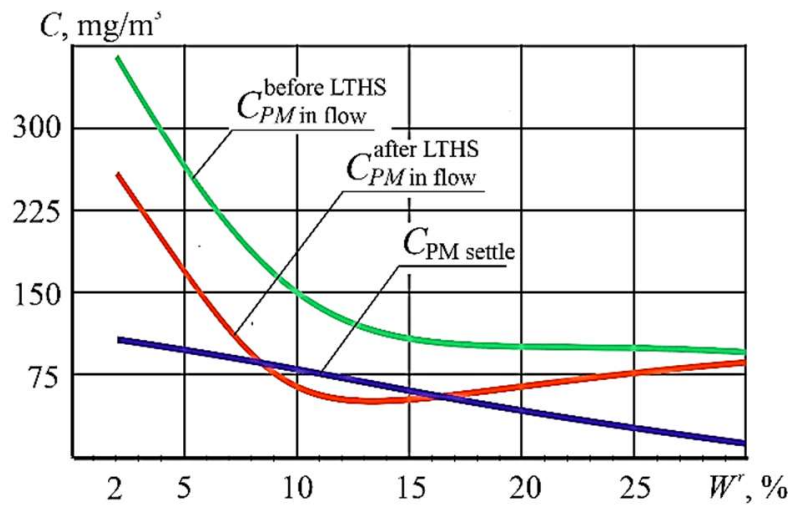

Fig. 3. Dependence of the change in the PM concentration in the exhaust gases before and after LTHS during the WFE combustion.

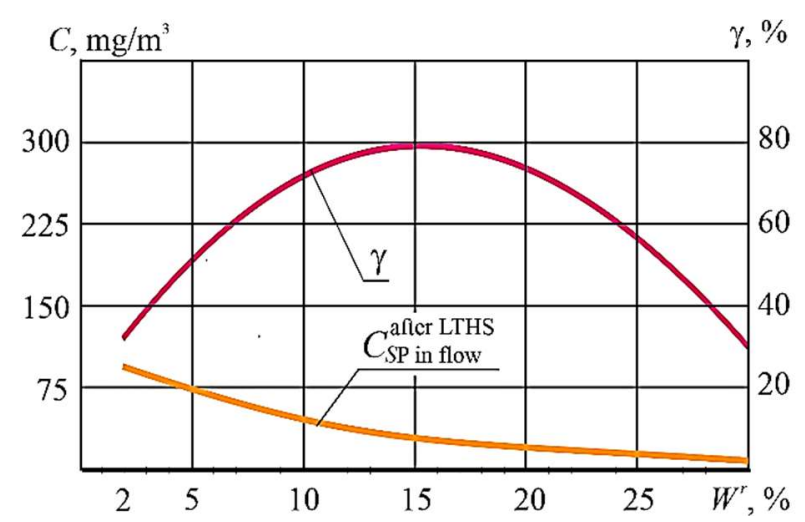

Fig. 4. Dependence of the change in the SP concentration in the exhaust gases after LTHS during the WFE combustion.

Despite the increasing moisture content of the surface with an increase of the water content $W^{r}$ to $10 \%$, due to a decrease of the size (mass) of particles (accordingly, the action of inertial forces) and the entrainment of small particles by the exhaust gas flow, the deposition intensity of these particles decreases.

With a further increase of the water content, the particle sizes continue to decrease, which should have led to a decrease of their deposition intensity. However, due to an increase of surface moisture and an increase in its adhesion effect, the deposition of such solid particles remains practically at the same level with an increase of the water content of WFE $W^{r}$ from 17 to $30 \%$.

Measurements of the particle concentration before and after the LTHS installed in the exhaust gas duct of experimental setup had shown that this heating surface ensures the capture of up to $30 \%$ of PM from the exhaust gas flow. By increasing of the surface size with a wall temperature below $120^{\circ} \mathrm{C}$, it is possible to capture up to $50 \%$ of particles from the flow. This is also confirmed by the decreasing values of the PM concentration, due to their deposition on the surface.

Taking into account the accepted rule of summing up the harmful effects of $\mathrm{NO}_{x}$ and $\mathrm{SO}_{2}$, the total toxicity index was determined for the maximum concentrations of ingredients (Fig. 5). 


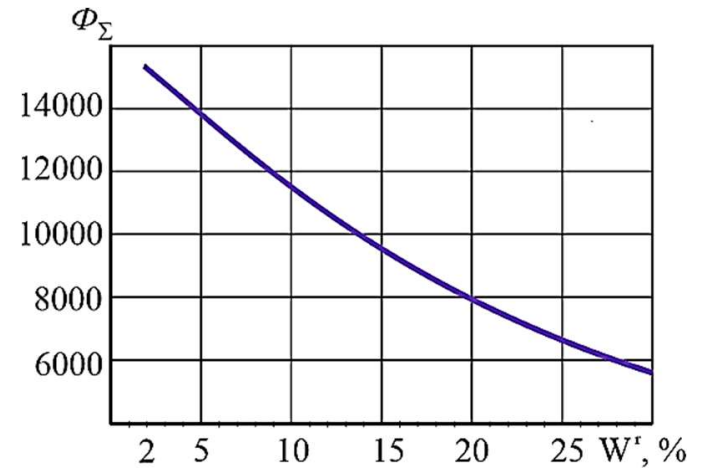

Fig. 5. Dependence of total toxicity index $\Phi_{\Sigma}$ of exhaust gases from water content of WFE.

When WFE combustion with a water content of $30 \%$, the toxicity $\Phi_{\Sigma}$ is significantly lower and amounts to 5750 (when fuel oil combustion $\Phi_{\Sigma}=15740$ ), i.e. the toxicity of exhaust gases during emulsion combustion is reduced by 2.7 times in comparison with fuel oil combustion.

\section{Conclusions}

The results of research have shown the presence of water vapor, their uniform distribution (as well as other components) over the torch volume due to "microexplosions" during the combustion of WFE, the uniform distribution and decrease in temperature in the combustion zone, the participation of $\mathrm{H}^{+}$and $\mathrm{OH}^{-}$ions in chemical reactions lead to reducing the emission of $\mathrm{NO}_{\mathrm{x}}$ and $\mathrm{SO}_{2}$ oxides.

Due to the condensation of water vapor and sulfuric acid vapor during the WFE combustion, nitrogen oxides are absorbed in the condensate, thereby the number of harmful substances in the emission is reduced.

When condensing economizer is installed, due to the absorption of a part of nitrogen oxides by condensate, the real toxicity of exhaust gases in the atmosphere will be significantly reduce (2.7 times).

\section{Nomenclature}

$$
\begin{aligned}
& C_{P M}^{\text {after in flow }}-\text { volume concentration of PM in exhaust } \\
& \text { gas flow after LTHS, }\left[\mathrm{m}^{3} / \mathrm{kg}\right] \\
& C_{P \text { before LTHS }} \\
& C_{P M}^{\text {before } \text { in flow }} \text { - volume concentration of PM in exhaust } \\
& \text { gas flow before LTHS, }\left[\mathrm{m}^{3} / \mathrm{kg}\right] \\
& C_{P M} \text { settle - volume concentration of PM deposited on } \\
& \text { the LTHS, }\left[\mathrm{m}^{3} / \mathrm{kg}\right] \\
& G_{P M}^{\text {after LTHS flow }} \text { - mass flow rate of PM in exhaust gas flow } \\
& \text { after LTHS, [g/h] } \\
& G_{P M}^{\text {before LTHS }}
\end{aligned}
$$

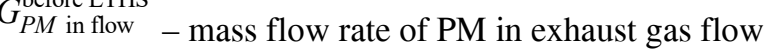

$$
\begin{aligned}
& \text { before LTHS, [g/h] } \\
& V_{\text {gas flow }} \quad-\text { volume flow rate of exhaust gases through } \\
& \text { the gas, }\left[\mathrm{m}^{3} / \mathrm{kg}\right] \\
& K_{p} \quad-\text { estimated amount of deposits on LTHS, } \\
& {\left[\mathrm{g} /\left(\mathrm{m}^{2} \cdot \mathrm{h}\right)\right]} \\
& Q_{i}^{r} \quad-\text { lowest heat of fuel combustion, }[\mathrm{kJ} / \mathrm{kg}]
\end{aligned}
$$

$$
\begin{array}{ll}
Q_{p}^{r} & - \text { highest heat of fuel combustion, }[\mathrm{kJ} / \mathrm{kg}] \\
S & - \text { total area of the outer surface of the experimental } \\
& \quad \text { samples, }\left[\mathrm{m}^{2}\right] \\
\gamma & - \text { degree of capture, }[\%] \\
\Phi_{\Sigma} & - \text { total toxicity index. }
\end{array}
$$

\section{References}

1. K.R. Patel, V. Dhiman, IJLERA 2, 37 (2017).

2. Y.C. Miao, C.L. Yu, B.H. Wang, K. Chen. Advanced Materials Research 779, 469 (2013).

3. P. Baskar, A. Senthil Kumar. Alexandria Engineering Journal 56, 137 (2017)

4. S. Vellaiyan, K.S. Amirthagadeswaran. Alexandria Engineering Journal 55, 2463 (2016)

5. R.K. Gupta, K.A. Sankeerth, T.K. Sharma, G. Rao, K.M. Murthy. Applied Mechanics and Materials 592, 1526 (2014)

6. V. Kornienko, R. Radchenko, Ł. Bohdal, L. Kukiełka, S. Legutko, Investigation of condensing heating surfaces with reduced corrosion of boilers with water-fuel emulsion combustion, in Integrated Computer Technologies in Mechanical Engineering (ICTM 2020), LNNS, 188, pp. 300309 (2021)

7. H. Chen, P. Pan, Y. Wang, Q. Zhao, Fuel 208, 149 (2017)

8. R. Radchenko, M. Pyrysunko, V. Kornienko, D. Konovalov, O. Girzheva, Enhancing energy efficiency of ship diesel engine with gas ecological recirculation, in Advances in Design, Simulation and Manufacturing IV, LNME, pp. 391-400 (2021)

9. O. Konur, O.Y. Saatcioglu, S.A. Korkmaz, A. Erdogan, C.O. Colpan, International Journal of Energy Research 44(15), 12312 (2020)

10. V. Kornienko, M. Radchenko, R. Radchenko, D. Konovalov, A. Andreev, M. Pyrysunko, Improving the efficiency of heat recovery circuits of cogeneration plants with combustion of water-fuel emulsions, Thermal Science 25 (1 Part B), 791800 (2021)

11. R. Radchenko, M. Pyrysunko, A. Radchenko, A. Andreev, V. Kornienko, Ship engine intake air cooling by ejector chiller using recirculation gas heat, in Advanced Manufacturing Processes, InterPartner-2020, LNME, pp. $734-743$ (2021)

12. S. Huang, C. Li, T. Tan, P. Fu, G. Xu, Y. Yang, Entropy 19, 423 (2017)

13. R. Radchenko, M. Pyrysunko, V. Kornienko, I.-C. Scurtu, R. Patyk, Improving the ecological and energy efficiency of internal combustion engines by ejector chiller using recirculation gas heat, in Integrated Computer Technologies in Mechanical Engineering, AISC, 188, pp. 531-541 (2021)

14. M. Radchenko, R. Radchenko, V. Kornienko, M. Pyrysunko, Semi-empirical correlations of pollution processes on the condensation surfaces 
of exhaust gas boilers with water-fuel emulsion combustion, in Advances in Design, Simulation and Manufacturing II (DSMIE 2019), LNME, pp. 853-862 (2020)

15. V. Kornienko, R. Radchenko, T. Bohdal, M. Radchenko, A. Andreev, Thermal characteristics of the wet pollution layer on condensing heating surfaces of exhaust gas boilers, in Advances in Design, Simulation and Manufacturing IV, LNME, pp. 339-348 (2021)

16. V. Kornienko, R. Radchenko, A. Stachel, A. Andreev, M. Pyrysunko, Correlations for pollution on condensing surfaces of exhaust gas boilers with water-fuel emulsion combustion, in: Advanced Manufacturing Processes, InterPartner2019, LNME, pp. 530-539 (2020)

17. L. Jiayou, S. Fengzhong, Energies 12, 706 (2019)

18. J. Deng, X. Wang, Z. Wei, L. Wang, C. Wang, Z. Chen, Science of the Total Environment 766, 144319 (2021)

19. S. Valluri, S.K. Kawatra, Journal of Environmental Sciences (China) 103, 279 (2021)

20. C. Esarte, J. Delgado, Energy and Fuels 32, 10106 (2018)

21. T. Olenius, A. Heitto, P. Roldin, T. Yli-Juuti, C. Duwig. Fuel 290, 120044 (2021)

22. V.P. Kotler, Yu.P. Enyakin, Teploenergetika 6, 2 (2004)

23. V.P. Bubnov, V.L. Bugaenko, V.L. Grishkin, G.A. Koroza, G.V. Nichipor, Teploenergetika 1, 42 (1993)

24. L. Bohdal, L. Kukielka, A.M. Radchenko, R. Patyk, M. Kułakowski, J. Chodór. Modelling of guillotining process of grain oriented silicon steel using FEM, in AIP Conference Proceeding 2078, 020080 (2019)

25. L. Bohdal, L. Kukiełka, S. Legutko, R. Patyk, A.M. Radchenko, Materials 13, 3175 (2020)

26. L. Bohdal, L. Kukielka, S. Świłło, A.M. Radchenko, A. Kułakowska, Modelling and experimental analysis of shear-slitting process of light metal alloys using FEM, SPH and visionbased methods, in AIP Conference Proceedings 2078, 020060 (2019)

27. E. Trushliakov A., Radchenko, M. Radchenko, S. Kantor, O. Zielikov, The efficiency of refrigeration capacity regulation in the ambient air conditioning systems, in Advances in Design, Simulation and Manufacturing III (DSMIE 2020), LNME, pp. 343-353 (2020)

28. E. Trushliakov, A. Radchenko, S. Forduy, A. Zubarev, A. Hrych, Increasing the operation efficiency of air conditioning system for integrated power plant on the base of its monitoring, in Integrated Computer Technologies in Mechanical Engineering (ICTM 2019), AISC, 1113, pp. 351360 (2020)

29. A. Radchenko, E. Trushliakov, V. Tkachenko, B. Portnoi, O. Prjadko, Improvement of the refrigeration capacity utilizing for the ambient air conditioning system, in Advanced Manufacturing Processes II, InterPartner 2020, LNME, pp. 714723 (2021)

30. M. Radchenko, M. Radchenko, A. Radchenko, R. Radchenko, S. Kantor, D. Konovalov, V.

Kornienko, Rational loads of turbine inlet air absorption-ejector cooling systems, Proceedings of the Institution of Mechanical Engineers, Part A: Journal of Power and Energy (2021). https://doi.org/10.1177/09576509211045455

31. A. Radchenko, A Stachel, S. Forduy, B. Portnoi, O. Rizun, Analysis of the efficiency of engine inlet air chilling unit with cooling towers, in Advances in Design, Simulation and Manufacturing III (DSMIE 2020), LNME, pp. 322-331 (2020)

32. A. Radchenko, E. Trushliakov, K. Kosowski, D. Mikielewicz, M. Radchenko, Energies 13, 6201 (2020)

33. M. Radchenko, R. Radchenko, V. Tkachenko, S. Kantor, E. Smolyanoy, Increasing the operation efficiency of railway air conditioning system on the base of its simulation along the route line, in Integrated Computer Technologies in Mechanical Engineering (ICTM 2019), AISC, 1113, pp. 461467 (2020)

34. M. Radchenko, D. Mikielewicz, V. Tkachenko, M. Klugmann, A. Andreev, Enhancement of the operation efficiency of the transport air conditioning system, in Advances in Design, Simulation and Manufacturing III (DSMIE 2020), LNME, pp. 332-342 (2020)

35. R. Radchenko, V. Kornienko, M. Pyrysunko, M. Bogdanov, A. Andreev, Enhancing the efficiency of marine diesel engine by deep waste heat recovery on the base of its simulation along the route line, in Integrated Computer Technologies in Mechanical Engineering (ICTM 2019), AISC, 1113, pp. 337-350 (2020)

36. D. Konovalov, H. Kobalava, M. Radchenko, I.C. Scurtu, R. Radchenko, Determination of hydraulic resistance of the aerothermopressor for gas turbine cyclic air cooling, in TE-RE-RD 2020, E3S Web of Conferences, 180, 01012 (2020)

37. V. Kornienko, R. Radchenko, D. Konovalov, A. Andreev, M. Pyrysunko. Characteristics of the rotary cup atomizer used as afterburning installation in exhaust gas boiler flue, in Advances in Design, Simulation and Manufacturing III (DSMIE 2020), LNME, pp. 302-311 (2020)

38. V. Kornienko, R. Radchenko, D. Mikielewicz, M. Pyrysunko, A. Andreev. Improvement of characteristics of water-fuel rotary cup atomizer in a boiler, in Advanced Manufacturing Processes, InterPartner-2020, LNME, pp. 664-674 (2021)

39. Thermal calculation of boiler units (Normative method). 3rd edn., NGO CKTI, St. Petersburg, (1998) 